Article

\title{
Impact of Land Use/Cover Changes on Soil Erosion in Western Kenya
}

\author{
Benjamin Kipkemboi Kogo ${ }^{1, * \mathbb{C}}$, Lalit Kumar ${ }^{1} \mathbb{( D )}$ and Richard Koech ${ }^{2}$ \\ 1 School of Environmental and Rural Science, University of New England, Armidale, NSW 2351, Australia; \\ lkumar@une.edu.au \\ 2 Department of Agriculture, Science and Environment, Central Queensland University, \\ Bundaberg, QLD 4670, Australia; r.koech@cqu.edu.au \\ * Correspondence: bkogo@myune.edu.au; Tel.: +61-421-077-454
}

Received: 9 October 2020; Accepted: 19 November 2020; Published: 22 November 2020

\begin{abstract}
This study examined the impact of land use/cover changes on soil erosion in western Kenya in the years 1995 and 2017. The study used the GIS-based Revised Universal Soil Loss Equation (RUSLE) modelling approach and remote sensing assessment. The results showed that the average soil loss through sheet, rill and inter-rill soil erosion processes was $0.3 \mathrm{t} / \mathrm{ha} / \mathrm{y}$ and $0.5 \mathrm{t} / \mathrm{ha} / \mathrm{y}$, in the years 1995 and 2017, respectively. Of the total soil loss, farms contributed more than 50\%, both in 1995 and 2017 followed by grass/shrub (7.9\% in 1995 and 11.9\% in 2017), forest (16\% in 1995 and $11.4 \%$ in 2017), and the least in built-up areas. The highest soil erosion rates were observed in farms cleared from forests ( 0.84 tons/ha) followed by those converted from grass/shrub areas ( 0.52 tons/ha). The rate of soil erosion was observed to increase with slope due to high velocity and erosivity of the runoff. Areas with high erodibility in the region are found primarily in slopes of more than 30 degrees, especially in Mt. Elgon, Chereng'anyi hills and Elgeyo escarpments. This study forms the first multi-temporal assessment to explore the extent of soil erosion and seeks to provide a useful knowledge base to support decision-makers in developing strategies to mitigate soil erosion for sustainable crop production.
\end{abstract}

Keywords: agricultural sustainability; land use/cover; land degradation; erosivity; erodibility; RUSLE; western Kenya

\section{Introduction}

Land degradation is a global environmental threat to ecosystem functions and agricultural productivity [1]. The major form of land degradation is soil erosion, which is caused by the impact of rain drops and runoff leading to soil detachment, transportation and deposition of soil [2]. Soil erosion triggers a series of impacts such as reduced productivity of agricultural lands through the loss of nutrient-rich top soil, depletion of soil organic matter content, degradation of soil structure and water retention capacity [3-6]. Soil erosion can also act as a pathway for carrying plant essential nutrients and farm chemicals to water sources [7]. The major underlying factors affecting the rate and severity of soil erosion are precipitation, topography, soil characteristics, vegetation/land cover changes, cropping systems and land management practices [8-10].

It is widely acknowledged that accelerated land degradation due to soil erosion is more acute in tropical countries of Africa than in non-tropical areas $[9,11]$. The causes of land degradation in the tropics are a complex nexus of intense climatic conditions, steep slopes, poor agricultural practices, high erosion-risk soils, overpopulation, lack of appropriate policies and overreliance on subsistence crop farming [12]. As per Ringius et al. [13], land degradation is a major problem in sub-Saharan Africa due to the lack of capacity to control and restore degraded soils. For example, in Kenya, it is estimated 
that approximately $30 \%$ of Kenya's landmass experiences severe soil degradation [14]. The dominant processes of land degradation that manifest in Kenya are the loss of soil fertility in agricultural lands through wind and water erosion, deforestation and desertification. Degradation of farms affects the majority of the rural people, who primarily depend on land for rural livelihoods, food, water and economic development [15].

The livelihood of the people of western Kenya is mainly based on mixed crop farming that is dominated by maize (Zea mays L.), a major staple crop for the country. The region faces a challenge of land use/cover changes resulting from high population pressure causing, among others, intensification of crop production, cultivation of steep lands, and deforestation [16]. In addition, a study by Waswa [17] found that over $55 \%$ of the farms in this region completely lacked soil and water conservation measures. Increasing degradation of farms in the region has led to increase in nutrient requirement for crop production $[18,19]$. However, there is limited information on spatial and temporal trends of soil erosion due to land use/land cover changes within the region. Unique to this study is the attempt to examine spatial patterns and magnitudes of soil erosion rates at multi-temporal scales for the region. A knowledge of soil loss at multiple time periods gives more plausibility in identifying possible hotspot areas that often experience greatest impacts of soil erosion risks. Such an assessment will better inform the policy makers on areas to focus resources to effectively monitor and mitigate soil losses in degraded lands [20].

In the past, the study of soil erosion was carried out through physical field assessments which, in most cases, were more challenging, costly and unpractical to map soil erosion risk in large spatial areas with complex environments [21-23]. Despite the challenges, field-based assessments can provide accurate and reliable data which are essential for validation of results from soil loss models [24,25]. In the recent past, soil loss and soil erosion risk mapping have been assessed using different empirical and stochastic models at regional and global levels [26]. A review study by Karydas et al. [27] identified 82 different modelling techniques that have been developed and used to examine soil loss from a field, hillslope or a watershed. These models have different geomorphological parameters that differ in extent and duration of application, influencing factors, processes, features examined, algorithms used and type of assessment. Among the models, RUSLE by Renard [28], which estimates annual soil loss per unit land area due to sheet and rill erosion, has emerged as the most widely used model globally. The RUSLE model predicts soil erosion at large spatial scales [29,30]. Some of the studies that have applied the RUSLE model include those by Mustefa et al. [31] in Ethiopia, Yang [8] in Australia, Panagos et al. [32] in Europe, Naqvi et al. [33] in India, Angima et al. [34], Shi et al. [35] in China, Nasir et al. [36] in Pakistan and Lu et al. [37] in Brazil. In Kenya, the RUSLE model has been used in studies undertaken by Angima et al. [34], Onyando et al. [38] and Mutua et al. [39]. In the recent past, modelling of soil loss has been carried out using RUSLE model integrated with GIS and remote sensing techniques to acquire and process satellite information, such as land use/cover, slope, aspect, etc. [22,40]. Integrating GIS and remote sensing makes it easier and faster to analyze and quantify the spatial extent of soil erosion in a catchment [41,42].

The main aim of this study was to examine the impact of land use/cover changes on soil erosion in western Kenya in the years 1995 and 2017. The specific objectives of the study were to: (1) estimate the extent of annual soil erosion and spatial distribution; (2) examine the contribution of topographic characteristics to soil erosion; and (3) determine how land use/cover types and changes contribute to soil erosion. It is hoped that the results of this study will provide useful information that can foster soil erosion management practices in western Kenya.

\section{Materials and Methods}

\subsection{Study Area}

The study area covers the Sio, Yala and Upper Nzoia sub-basins of Lake Victoria North Catchment area (Figure 1). A summary of the sub-basin characteristics is presented in Table 1. The region experiences 
bimodal rainfall, whose distribution is greatly influenced by the relief and altitude as well its proximity to Lake Victoria. The major soil types in the region include: (1) Acrisols (clay-rich soils that are highly susceptible to erosion); (2) Nitisols (predominantly deep and well-drained soils with stable structure and good nutrient content); (3) Ferralsols (well drained soils with low nutrients and largely dominant in flat to undulating land); and (4) Cambisols (young soils, good for agriculture) that are good for a wide variety of crops $[18,43,44]$.
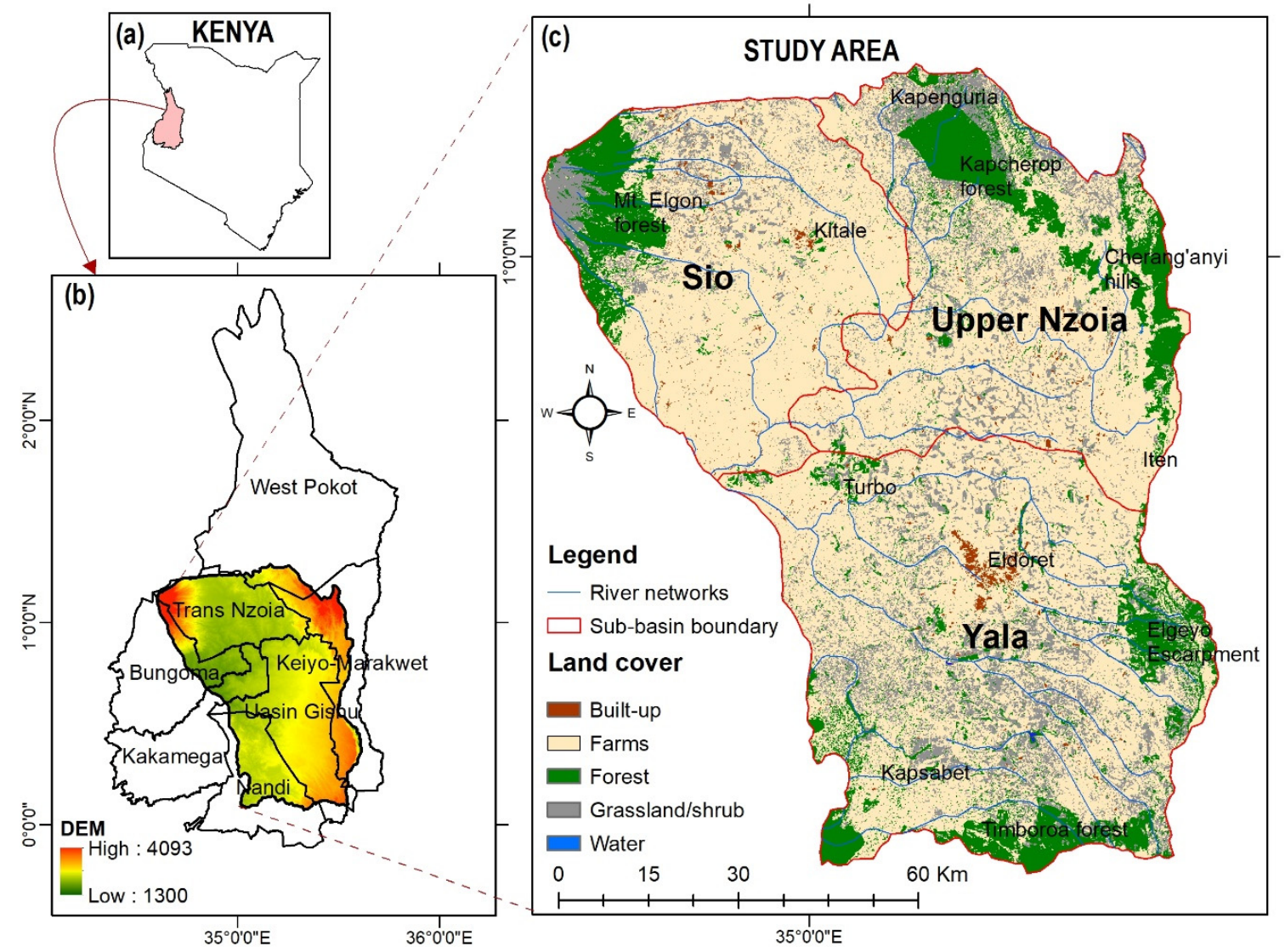

Figure 1. Location map of the study area: (a) Map of Kenya showing the western region; (b) Digital elevation model and counties in the study area; (c) map of study area showing the major towns, river networks, sub-basin boundaries, and land use/cover classification of 2017 by Kogo et al. [45].

Table 1. Characteristics of the sub-basins.

\begin{tabular}{cccccc}
\hline Sub-Basin & $\begin{array}{c}\text { Surface Area } \\
\left(\mathbf{1 0}^{\mathbf{4}} \mathbf{h a}\right)\end{array}$ & $\begin{array}{c}\text { Temperature } \\
\left.\mathbf{(}{ }^{\circ} \mathbf{C}\right)\end{array}$ & $\begin{array}{c}\text { Rainfall } \\
\mathbf{( m m})\end{array}$ & $\begin{array}{c}\text { Average Slope } \\
\text { (Degrees) }\end{array}$ & $\begin{array}{c}\text { Altitude } \\
(\mathbf{m} \text { a.m.s. })\end{array}$ \\
\hline Sio & 3.3 & $10-30$ & $400-1800$ & 5.5 & $1.543-4.093$ \\
Upper Nzoia & 36.6 & $10-29$ & $600-2214$ & 7.2 & $1.561-3.202$ \\
Yala & 54.9 & $15-29$ & $624-1560$ & 4.6 & $1.300-2.803$ \\
\hline
\end{tabular}

The land use/cover distribution in the study years 1995 and 2017 is presented in Figure 2. From the assessment, farms occupy over $50 \%$ of the total land area in the region. Among the land use/covers, areas under farms increased from $51.4 \%$ to $67.6 \%$ in 2017 , which is the highest compared to others, in the years 1995 and 2017, respectively. There was also an increase of built-up areas from $0.3 \%$ in 1995 to $1.5 \%$ in 2017. On the contrary, forest and grass/shrub areas decreased from $22.2 \%$ and $26 \%$ in 1995 to $15.3 \%$ and 15.5\% in 2017, respectively. According to Kogo et al. [45] the decrease in forest and grass/shrub land is due to conversion to farms and built-up areas in different parts of the region. 
The major drivers of such conversions are population pressure leading to increased demand for food production and settlement.

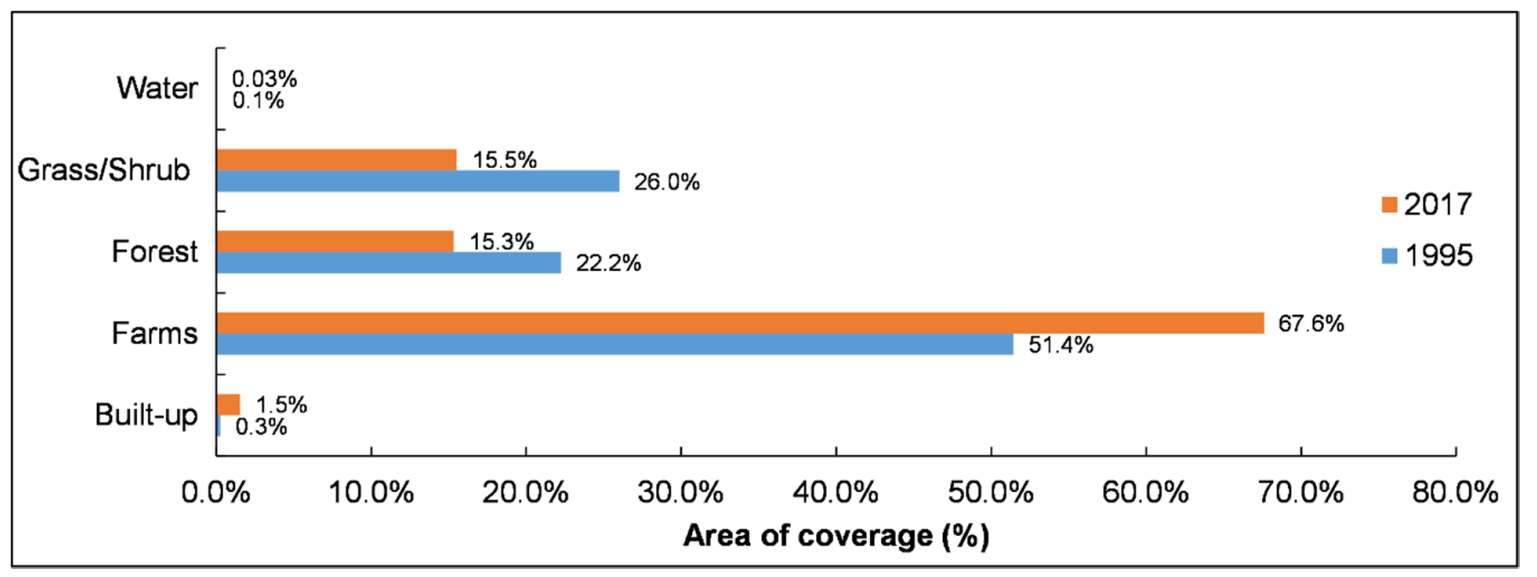

Figure 2. Land use/cover distribution in the years 1995 and 2017 (adapted from Kogo et al. [45]).

\subsection{Methodology}

In this study, the overall methodology involved the use of the GIS-based Revised Universal Soil Loss Equation (RUSLE) modelling approach. RUSLE is an empirical modelling approach that is commonly used to compute long-term surface erosion, mainly gross sheet and rill erosion $[2,46]$. The model was developed through modification of the USLE to improve on accuracy in estimation of soil loss [28]. The annual soil loss using the RUSLE model is computed as:

$$
A=R \times K \times(L S) \times C \times P
$$

where:

$A=$ computed amount of the average annual soil loss per unit area $(\mathrm{t} / \mathrm{ha} / \mathrm{y})$,

$R=$ Rainfall erosivity factor (MJ $\mathrm{mm} / \mathrm{ha} / \mathrm{h} /$ year),

$K=$ soil erodibility factor (ton $\mathrm{h} / \mathrm{MJ} / \mathrm{mm}$ ),

$L S=$ Slope length and slope steepness factor (dimensionless),

$C=$ ground cover factor (dimensionless),

$P=$ soil conservation supporting practice factor (dimensionless).

The common datasets used in RUSLE modelling of soil erosion are the rainfall, soil, topographic data from a digital elevation model (DEM) and land use/cover classification (LULC), respectively. Soil loss in this study was computed for the years 1995 and 2017, corresponding to a LULC assessment for the region undertaken by the authors in a recent study Kogo et al. [45]. The basic methodology followed in determination of each of the RUSLE factors is described below.

\subsubsection{Determination of Rainfall-Runoff Erosivity Factor (R)}

The $R$-factor is a measure of the erosive power of the average annual rainfall intensity on runoff and initiation of soil movement. Gridded rainfall point data at a $4 \times 4 \mathrm{~km}$ spatial resolution acquired from the Kenya Meteorological Department (KMD) was used as input for determining the rainfall erosivity. The study area had no data on rainfall intensity, and thus monthly rainfall data were used to compute erosivity using Equation (2) by Wischmeier and Smith [2]. Rainfall data obtained over a time span of 1981-1995 and 2002-2017 were used to determine erosivity for the years 1995 and 2017, respectively.

$$
R=\sum_{i=1}^{12} 1.735 \times 10^{\left(1.5 \log 10\left(\frac{P_{i}^{2}}{P}\right)-0.08188\right)}
$$


where $R$ is the rainfall erosivity (MJ $\mathrm{mm} / \mathrm{ha} / \mathrm{h} /$ year), $P i$ is the monthly rainfall ( $\mathrm{mm}$ ) and $P$ is the annual rainfall ( $\mathrm{mm}$ ). The computed values of $R$-factor for each point were then interpolated using the ordinary Kriging method to obtain their spatial distribution in the study area. Kriging is a widely used geostatistical analytical method that uses the spatial characteristics of observed data to estimate the values at unsampled locations $[47,48]$. This technique is the most appropriate since it has been confirmed to present better estimates compared to other interpolation methods [49]. The resulting $\mathrm{R}$-values for the various study years were then converted into raster layers.

\subsubsection{Determination of Soil Erodibility Factor (K)}

The K-factor accounts for response of the soil profile to the detachment of soil by raindrops and transport by water runoff [28]. In this study, soil data were acquired from the Soil and Terrain Database for Kenya (KENSOTER) database [50]. The soil information extracted from the database for use in the assessment of soil erodibility included sand, silt, clay, and organic carbon. Using the above soil parameters, K-factor was computed using Equations (3) to (7) [51].

$$
K_{\text {Rusle }}=f_{\text {csand }} \times f_{c l-s i} \times f_{\text {orgC }} \times f_{\text {hisand }}
$$

where:

$$
\begin{gathered}
f_{\text {csand }}=0.2+0.3 \times \exp \left[-0.256 \times M s \times\left(1-\frac{M \text { silt }}{100}\right)\right] \\
f_{c l-s i}=\left[\frac{M \text { silt }}{M c+M s i l t}\right]^{0.3} \\
f_{\text {org } C}=\frac{0.0256 \times M o}{M o+\exp [3.72-(2.95 \times M o)]} \\
f_{\text {hisand }}=1-0.7 \times \frac{1-\frac{M s}{100}}{\left(1-\frac{M s}{100}\right)+\exp \left[-5.51+22.9 \times\left(1-\frac{M s}{100}\right)\right]}
\end{gathered}
$$

where $M s$ is the \% sand, Msilt is \% silt, Mc is the \% clay and Mo is \% organic matter. The values of the $K$-factor are in the range from 0 to 1 , where values tending towards 1 indicate an increase in susceptibility to erosion by water [51]. The same K-factor was used in the two study years since there were no separate data for the different time periods.

\subsubsection{Determination of Topographic Factor (LS)}

The LS-factor combines both the length and steepness of land slope and thus, considerably affects the rate of soil loss. This factor was computed from the DEM of Kenya at a spatial resolution of $30 \mathrm{~m}$ extracted from the Shuttle Radar Topography Mission (SRTM) database available at http://opendata.rcmrd.org/datasets/kenya-srtm-dem-30meters, accessed April 2020. In computing the LS factor, the Hydrology tool in ArcGIS was employed to undertake DEM sink filling before generating the flow direction and accumulation. The surface slope angle was then computed from the DEM, and the LS factor calculated using the following equation as recommended by Morgan [52]:

$$
L S=\left(\frac{\lambda}{22.13}\right)^{m} \times\left(0.065+0.045 s+0.0065 s^{2}\right)
$$

where: $\lambda$ is the slope length given by flow accumulation $\times$ cell resolution ( $30 \mathrm{~m}$ for this study), $s$ is the slope gradient in percent; $m=$ dimensionless exponent based on the steepness of land. The values of $m$ area assigned as: $0.5,0.4,0.3$ and 0.2 for slopes of $>5 \%, 3-5 \%, 1-3 \%$ and $<1 \%$, respectively [53]. The same LS-factor was used for both study years. 


\subsubsection{Determination of Conservation Practice Factor (P)}

The $P$-factor accounts for the conservation measures that minimize the amount of runoff water in erosion of soil. This factor depends on land use/cover information. This study used the raster images of a LULC assessment for the years 1995 and 2017. The raster images were merged with slope classes derived from the DEM using 'union function' in ArcGIS and the values of $P$-factor suggested by Wischmeier and Smith [2] were assigned (Table 2).

Table 2. Land use/cover type and corresponding P-factor values.

\begin{tabular}{ccc}
\hline Land Use Type & Slope (\%) & P-factor \\
\hline Farms & $0-5$ & 0.1 \\
& $5-10$ & 0.12 \\
& $10-20$ & 0.14 \\
& $20-30$ & 0.19 \\
Others (built-up, forest, water, grass/shrub land) & $30-50$ & 0.25 \\
& $50-100$ & 0.33 \\
\end{tabular}

Source: [2].

\subsubsection{Determination of Cover Management Factor (C)}

The C-factor accounts for the contribution of land cover towards soil loss, and is thus an essential and dynamic element of the RUSLE model [8]. The Normalised Difference Vegetation Index (NDVI) is used to estimate the C-factor because of its dynamic nature. In this study, the NDVI values were extracted from the Landsat images that were used in the aforementioned study of land use/cover changes of western Kenya [45]. The $C$-factor has an inverse relationship with NDVI and was computed using Equation (9) by Van der Knijff et al. [54]:

$$
C=\exp \left[-a \frac{N D V I}{\beta-N D V I}\right]
$$

where $a=2, \beta=1$ and NDVI $=($ Near Infrared - Red $) /($ Near Infrared + Red $)$ as obtained from satellite imagery. The range of $C$-factor values is 0 for complete vegetation cover to 1 for bare lands [55].

\subsubsection{Spatial Distribution of Soil Loss}

The derived raster layers of each of the RUSLE factors were projected to WGS 1984 UTM Zone $37 \mathrm{~N}$ spatial reference and resampled to a $30 \times 30 \mathrm{~m}$ pixel size. The layers were superimposed and multiplied in ArcGIS to get soil erosion risk maps for the study years. The generated maps were further classified into four erosion classes namely: slight, moderate, high and very high, with erosion rates of less than 5, 5-10, 10-20 and above $20 \mathrm{t} / \mathrm{ha} / \mathrm{y}$, respectively. Average quantities of soil erosion rates were computed under different elevation and slope categories.

The contribution of land use/cover conversion towards soil erosion risk in the region was computed through the following steps: (1) change analysis to determine nature of conversions that have taken place among the various LULC classes between 1995 and 2017; (2) Overlay of the LULC conversion images with slope map to determine the nature and magnitude of alterations that have taken place in various slope categories; (3) computation of the quantities and rates of soil erosion resulting from the LULC conversions at various slopes.

A summary of the methodology is presented in Figure 3. 


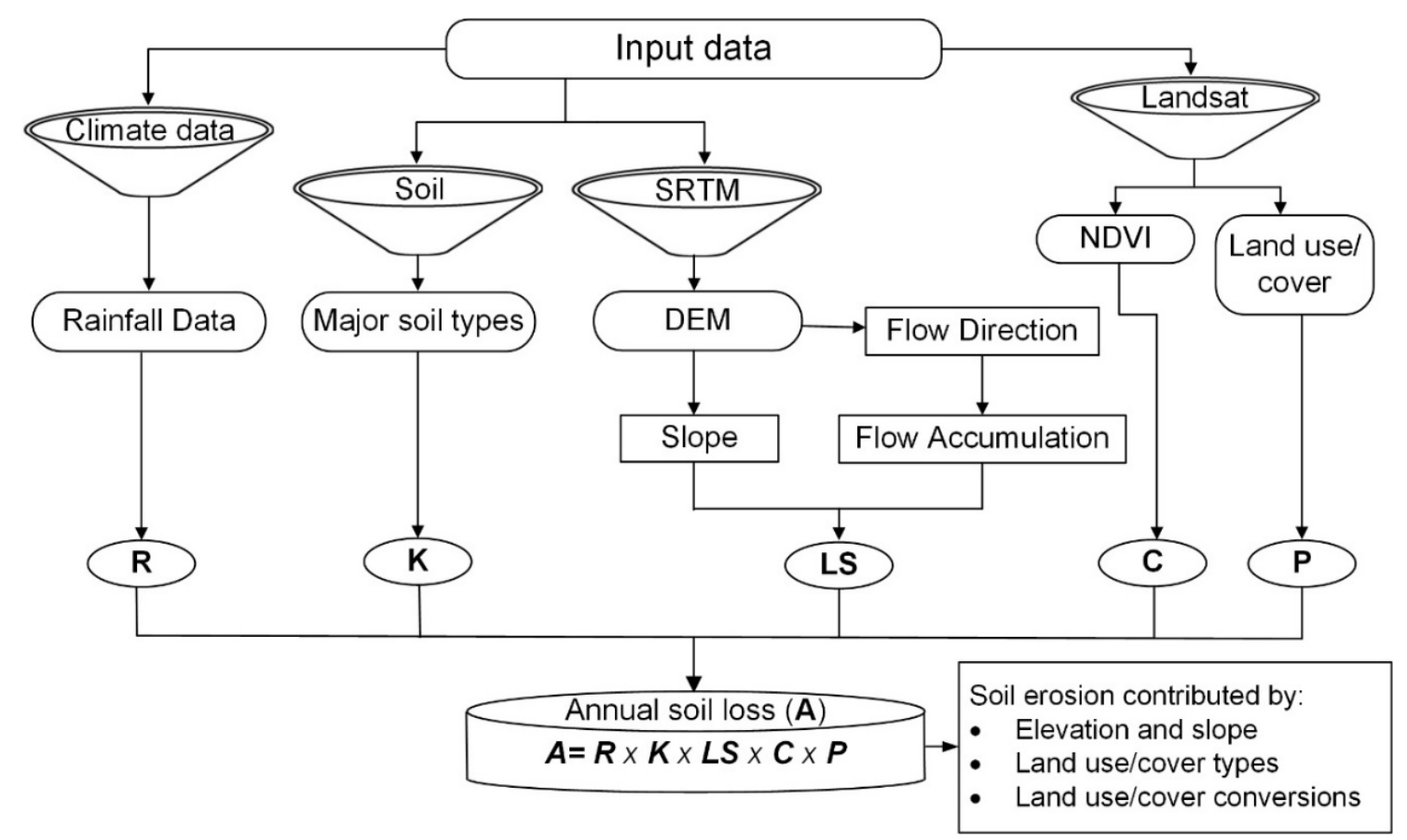

Figure 3. Flow chart of the methodology used to determine the spatial distribution of soil loss.

\section{Results}

\subsection{RUSLE Factors}

The various RUSLE factors determined in this study are presented in Figures 4 and 5 . The rainfall erosivity (R-factor) values were in the range of 335 to $653 \mathrm{MJ} \mathrm{mm} / \mathrm{ha} / \mathrm{h} /$ year (mean of $474 \mathrm{MJ} \mathrm{mm} / \mathrm{ha} / \mathrm{h} / \mathrm{year}$ ) in the year 1995. In the study year 2017, the value ranged from 282 to $824 \mathrm{MJ} \mathrm{mm} / \mathrm{ha} / \mathrm{h} / \mathrm{year}$ (mean of $436 \mathrm{MJ} \mathrm{mm} / \mathrm{ha} / \mathrm{h} /$ year). Both the cover management factor (C-factor); and (c) conservation practice (P-factor) values were in the range of 0 to 1 . The soil erodibility (K-factor) values were found to range from 0.09 to 0.47 tons $\mathrm{h} / \mathrm{MJ} / \mathrm{mm}$ and the LS factor values ranged from 0 to 20.6 (Figure 5). 


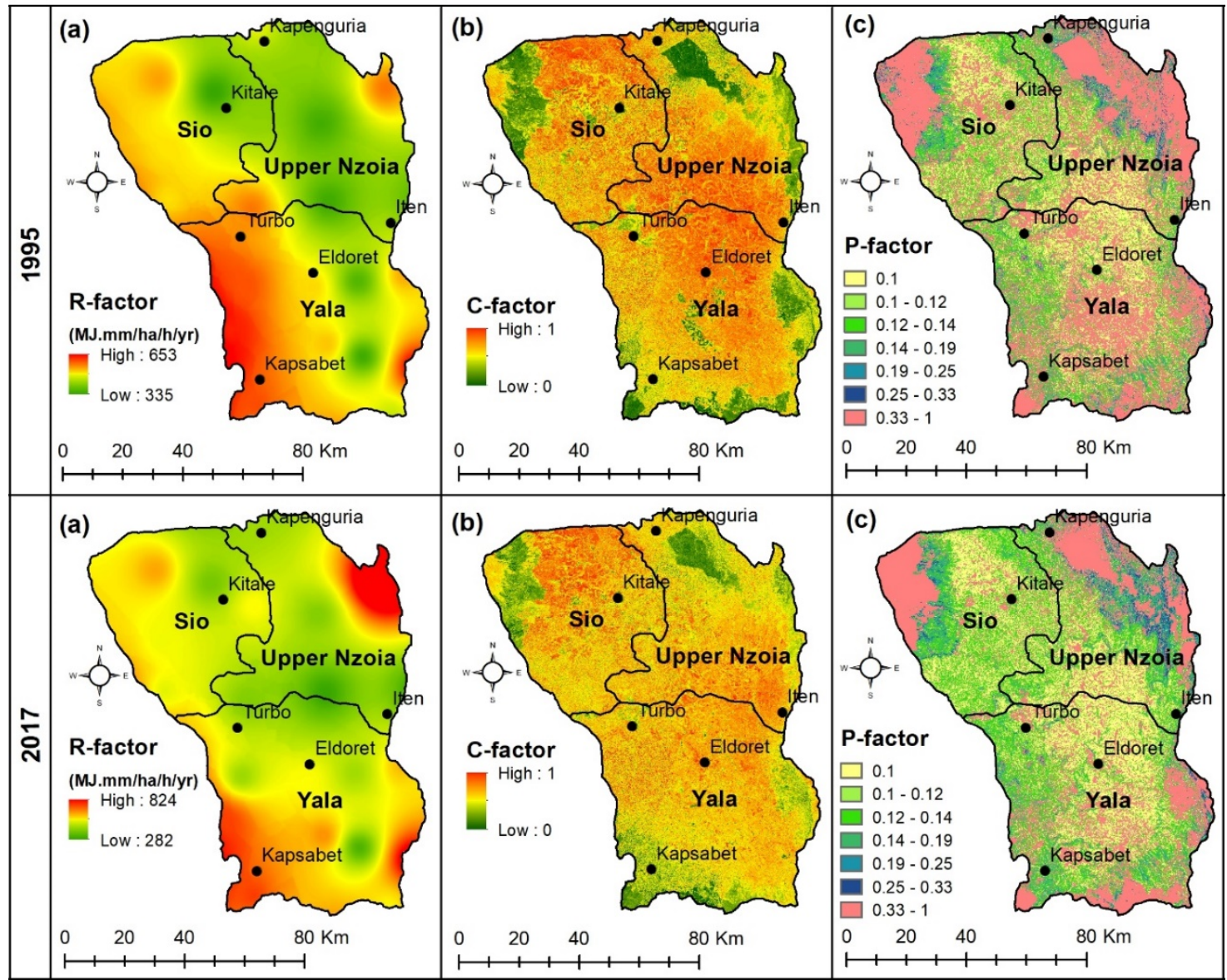

Figure 4. Spatial distribution of: (a) rainfall-runoff erosivity (R-factor) (b) cover management (C-factor); and (c) conservation practice (P-factor) for the years 1995 and 2017.
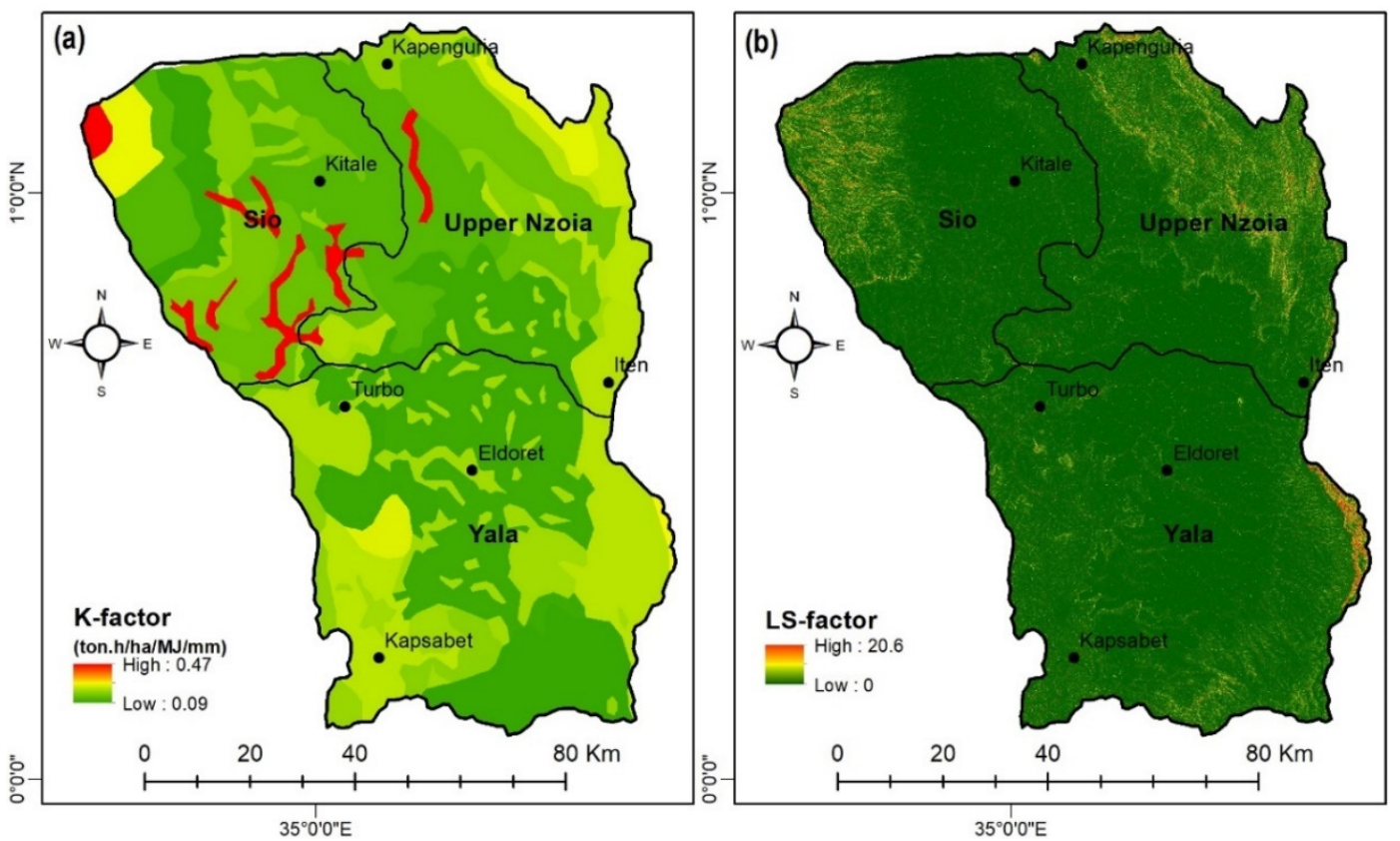

Figure 5. Spatial distribution of: (a) soil erodibility (K-factor) and (b) topographic (LS-factor). 


\subsection{Spatial and Temporal Soil Losses}

The study revealed that the soil lost through sheet and rill erosion in western Kenya was in the range of 0-36.8 t/ha/y in 1995 and 0-45.2 t/ha/y in 2017, respectively (Figure 6). In the year 1995, the total amount of soil erosion was 167,950 tons, distributed as follows: the highest (38.3\%) in Yala, 28.4\% in Sio and 33.4\% in Upper Nzoia sub-basins (Table 3). Likewise, the amount of soil erosion in the year 2017 was 319,790 tons distributed as follows: 38.4\% in Yala, 23.5\% in Sio and 38.1\% in Upper Nzoia sub-basins.
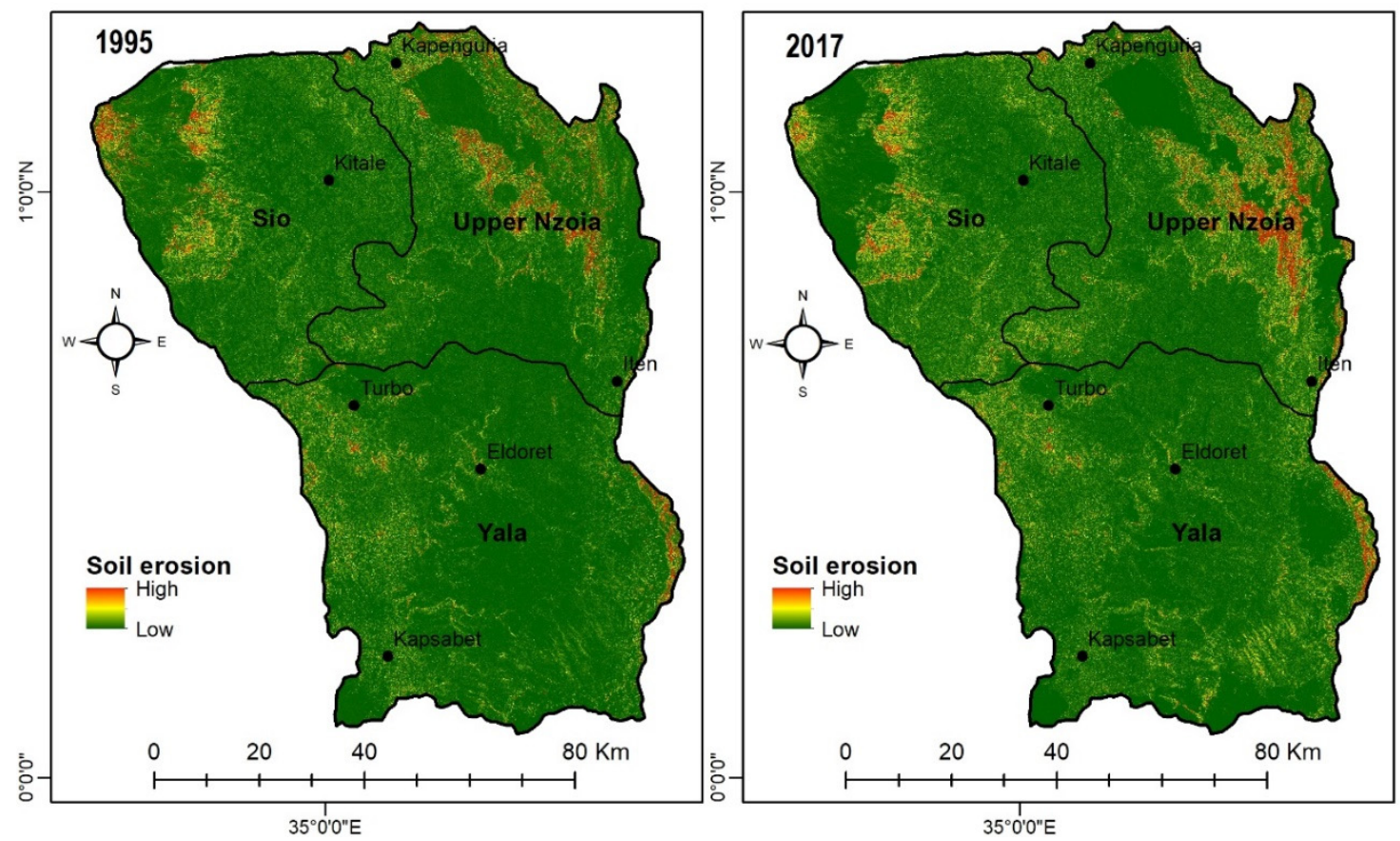

Figure 6. Spatial distribution of soil loss in the sub-basins within the study area.

Table 3. Distribution of soil loss in various sub-basins.

\begin{tabular}{ccccc}
\hline \multirow{2}{*}{ Sub-Basin } & \multicolumn{2}{c}{ Soil Loss (1995) } & \multicolumn{2}{c}{ Soil Loss (2017) } \\
\cline { 2 - 5 } & $\mathbf{t} / \mathbf{y}$ & Percent & $\mathbf{t} / \mathbf{y}$ & Percent \\
\hline Yala & 6.4 & 38.3 & 12.3 & 38.4 \\
Sio & 4.7 & 28.4 & 7.5 & 23.5 \\
Upper Nzoia & 5.6 & 33.4 & 12.2 & 38.1 \\
\hline Total for the region & 16.8 & & 32.0 & \\
\hline
\end{tabular}

Soil loss was further classified into different soil erosion severity classes namely: low (less than $5 \mathrm{t} / \mathrm{ha} / \mathrm{y})$, moderate (5-10 t/ha/y), high (10-20 t/ha/y) and very high ( $>20 \mathrm{t} / \mathrm{ha} / \mathrm{y})$, as shown in Table 4 . The areas that experience low erosion rates were dominant in the study area, covering 614,756 ha (with average soil loss of $0.2 \mathrm{t} / \mathrm{ha} / \mathrm{y}$ ) and 611,581 ha (with average soil loss of $0.4 \mathrm{t} / \mathrm{ha} / \mathrm{y}$ ) in the years 1995 and 2017, respectively. In the year 1995, the areas that experienced moderate erosion (6.8 t/ha/y), high erosion (13.5 t/ha/y) and very high erosion ( $31.5 \mathrm{t} / \mathrm{ha} / \mathrm{y})$ were $2788 \mathrm{ha}, 1031$ ha and $385 \mathrm{ha}$, respectively. In the year 2017, areas that experienced moderate erosion (6.7 t/ha/y), high erosion (13.4 t/ha/y) and very high erosion (35.8 t/ha/y) were 5188 ha, 1697 ha and 493 ha, respectively. The highest increase in soil erosion by $4.3 \mathrm{t} / \mathrm{ha} / \mathrm{y}$ was observed in areas prone to very high erosion rates. 
Table 4. Distribution of soil loss under different severity classes.

\begin{tabular}{|c|c|c|c|c|c|c|}
\hline \multirow{2}{*}{$\begin{array}{l}\text { Class of } \\
\text { Severity }\end{array}$} & \multirow{2}{*}{$\begin{array}{l}\text { Soil Loss } \\
\text { (t/ha/y) }\end{array}$} & \multicolumn{2}{|c|}{ Year 1995} & \multicolumn{2}{|c|}{ Year 2017} & \multirow{2}{*}{$\begin{array}{c}\text { Net Change } \\
(\mathrm{t} / \mathrm{ha} / \mathrm{y})\end{array}$} \\
\hline & & $\begin{array}{l}\text { Area } \\
\text { (ha) }\end{array}$ & $\begin{array}{l}\text { Soil Loss } \\
\text { (t/ha/y) }\end{array}$ & $\begin{array}{l}\text { Area } \\
\text { (ha) }\end{array}$ & $\begin{array}{l}\text { Soil Loss } \\
\text { (t/ha/y) }\end{array}$ & \\
\hline Low & $<5$ & 614,756 & 0.2 & 611,581 & 0.4 & 0.2 \\
\hline Moderate & 5-10 & 2788 & 6.8 & 5188 & 6.7 & -0.1 \\
\hline High & $10-20$ & 1031 & 13.5 & 1697 & 13.4 & -0.1 \\
\hline Very High & $>20$ & 385 & 31.5 & 493 & 35.8 & 4.3 \\
\hline
\end{tabular}

\subsection{Effect of Elevation and Slope on Soil Erosion}

The elevation map of the study area was divided into five different elevation zones and the corresponding soil erosion rates computed (Table 5). The rate of soil loss at elevations that are less than $2000 \mathrm{~m}(285,000 \mathrm{ha})$ were $0.2 \mathrm{t} / \mathrm{ha} / \mathrm{y}$ in 1995 and $0.4 \mathrm{t} / \mathrm{ha} / \mathrm{y}$ in 2017. The rate of soil loss for elevation of 2000-2500 m (264,300 ha) was $0.3 \mathrm{t} / \mathrm{ha} / \mathrm{y}$ in 1995 and $0.6 \mathrm{t} / \mathrm{ha} / \mathrm{y}$ in 2017. Likewise, the rate of soil loss for elevation of 2500-3000 m (60,200 ha) was $0.3 \mathrm{t} / \mathrm{ha} / \mathrm{y}$ in 1995 and $0.7 \mathrm{t} / \mathrm{ha} / \mathrm{y}$ in 2017, the change being the highest soil loss amounting to $1.7 \mathrm{t} / \mathrm{ha} / \mathrm{y}$. The results show a decrease in soil loss of approximately $0.3 \mathrm{t} / \mathrm{ha} / \mathrm{y}$ and $3.5 \mathrm{t} / \mathrm{ha} / \mathrm{y}$ that was realized at elevations of $3000-3500 \mathrm{~m}$ (7800 ha) and those above $3500 \mathrm{~m}$ (1600 ha), respectively.

Table 5. Estimate of soil erosion rates and net changes in different elevation zones.

\begin{tabular}{ccccc}
\hline \multirow{2}{*}{ Elevation } & $\begin{array}{c}\text { Area } \\
\left(\mathbf{1 0}^{\mathbf{4}} \mathbf{h a}\right)\end{array}$ & \multicolumn{2}{c}{ Erosion $\mathbf{( t / h a / \mathbf { y } )}$} & \multirow{2}{*}{$\begin{array}{c}\text { Net Change } \\
(\mathbf{t} / \mathbf{h} \mathbf{a} / \mathbf{y})\end{array}$} \\
\cline { 3 - 4 } & 28.50 & $\mathbf{1 9 9 5}$ & $\mathbf{2 0 1 7}$ & \\
20.2 & 0.4 & 0.2 \\
$2000-2500$ & 26.43 & 0.3 & 0.6 & 0.3 \\
$2500-3000$ & 6.02 & 0.3 & 0.7 & 0.4 \\
$3000-3500$ & 0.78 & 0.8 & 0.5 & -0.3 \\
$>3500$ & 0.16 & 4.4 & 0.9 & -3.5 \\
\hline
\end{tabular}

Soil loss was further distributed as per slope of occurrence (Table 6). The rates of soil erosion showed an increase with increase in slope, with the lowest rates being $0.2 \mathrm{t} / \mathrm{ha} / \mathrm{y}$ in 1995 and $0.3 \mathrm{t} / \mathrm{ha} / \mathrm{y}$ in 2017 , which occurred in slopes that were less than $5^{\circ}$ (387,000 ha). In slopes of 5-10 (138,000 ha), the rates of soil loss were $0.3 \mathrm{t} / \mathrm{ha} / \mathrm{y}$ in 1995 and $0.4 \mathrm{t} / \mathrm{ha} / \mathrm{y}$ in 2017. In addition, the rate of soil loss in slopes of $10-20^{\circ}$ (77,000 ha) was $0.4 \mathrm{t} / \mathrm{ha} / \mathrm{y}$ in 1995 and $0.7 \mathrm{t} / \mathrm{ha} / \mathrm{y}$ in 2017 . Slopes of 20-30 (14,000 ha) depicted cited soil erosion rates of $1.4 \mathrm{t} / \mathrm{ha} / \mathrm{y}$ in 1995 and $2.4 \mathrm{t} / \mathrm{ha} / \mathrm{y}$ in 2017. Slopes of more than $30^{\circ}$ (3000 ha) had soil erosion rates of $3.2 \mathrm{t} / \mathrm{ha} / \mathrm{y}$ in 1995 and $4.9 \mathrm{t} / \mathrm{ha} / \mathrm{y}$ in 2017.

Table 6. Soil erosion in slope zones and net changes between the years 1995 and 2017.

\begin{tabular}{ccccc}
\hline \multirow{2}{*}{ Slope } & $\begin{array}{c}\text { Area } \\
\left(\mathbf{1 0}^{\mathbf{4}} \mathbf{h a}\right)\end{array}$ & \multicolumn{2}{c}{ Erosion (t/ha/y) } & \multirow{2}{*}{$\begin{array}{c}\text { Net Change } \\
(\mathbf{t} / \mathbf{h a} / \mathbf{y})\end{array}$} \\
\cline { 3 - 4 } & & $\mathbf{1 9 9 5}$ & $\mathbf{2 0 1 7}$ & \\
\hline$<5^{\circ}$ & 38.7 & 0.2 & 0.3 & 0.1 \\
$5-10^{\circ}$ & 13.8 & 0.3 & 0.4 & 0.1 \\
$10-20^{\circ}$ & 7.7 & 0.4 & 0.7 & 0.3 \\
$20-30^{\circ}$ & 1.4 & 1.4 & 2.4 & 1.0 \\
$>30^{\circ}$ & 0.3 & 3.2 & 4.9 & 1.7 \\
\hline
\end{tabular}

\subsection{Contribution of Land Use/Cover Types and Conversions to Soil Erosion}

Distribution of soil loss in different LULCs showed that farms had the highest occurrence of soil erosion; $55.3 \%$ and 69.6\% in the years 1995 and 2017, respectively (Figure 7). Soil loss in grass/shrub 
lands was $7.9 \%$ in 1995 and $11.9 \%$ in 2017. The other land cover that had significant soil loss were forested areas where $16 \%$ and $11.4 \%$ of soil erosion occurred in the years 1995 and 2017, respectively.

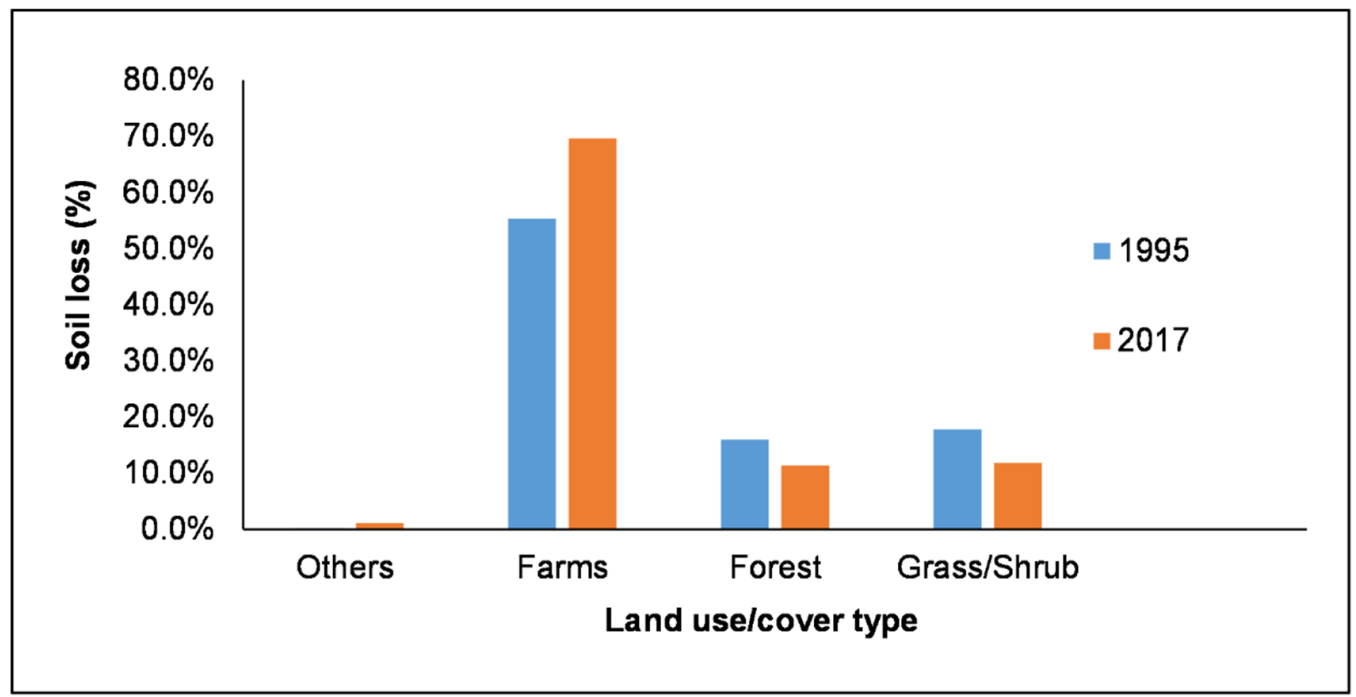

Figure 7. Contribution of various land uses to total soil erosion.

The spatial distribution of the LULC conversions and their contribution to soil erosion is presented in Figure 8. The major form of LULC change was conversion of 108,103 ha of grass/shrub land and 48,729 ha of forestland to farms, leading to total soil loss of 56,260 tons and 40,696 tons, respectively. Other conversions were 5347 ha of grassland and 14,620 ha of farms to forest. In addition, 37,749 ha of farms and 13,504 ha of forest were converted to grass/shrub land. The highest soil erosion rates of 0.84 tons/ha and 0.52 tons/ha were realized in the conversion of forest and grass/shrub lands to farms, respectively.
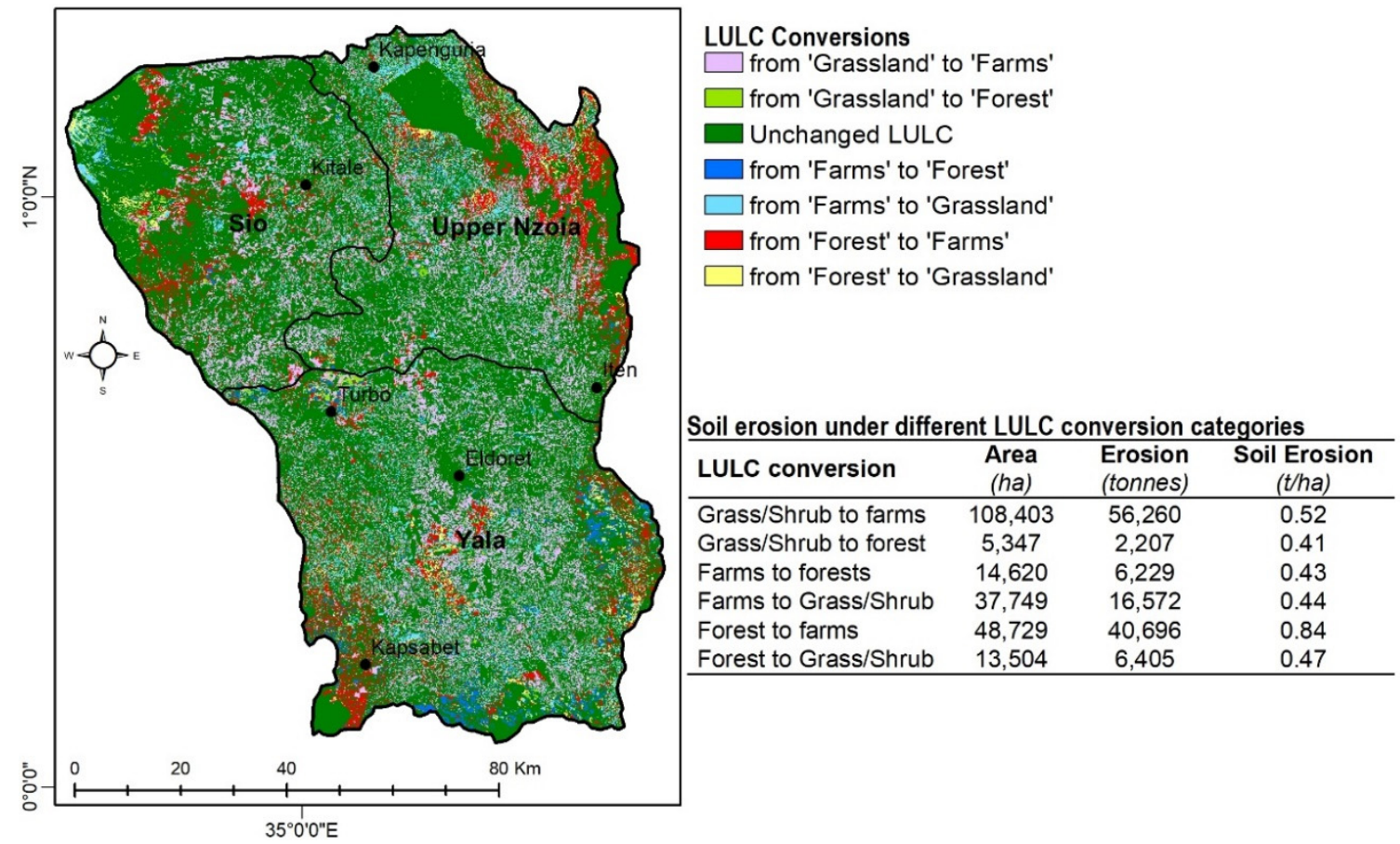

Figure 8. Map showing the spatial distribution of the land use/cover classification (LULC) conversions that have occurred in the study area between 1995 and 2017. The inset table presents the areas, quantities and rates of soil erosion under the various LULC conversion categories. 
The magnitude of LULC conversions in the various slope categories is presented in Table 7. The results show that the highest conversion types were recorded in the loss of 82,526 ha and 18,830 ha of grass/shrub lands to farms in areas with slopes of $<5^{\circ}$ and $5-10^{\circ}$, respectively. Conversion of forest to farms was dominant in slopes of $10-20^{\circ}$ (11,157 ha), 20-30 (2582 ha) and $>30^{\circ}$ (463 ha). Likewise, quantities of soil loss through erosion were observed to take almost a similar trend to LULC conversions at various slopes, as demonstrated above (Table 8). For instance, soil loss was the highest ( 42,831 tons) in the conversion of grass/shrub land to farms at slopes of $<5^{\circ}$. The conversion of forest to farms lead to the highest soil loss of 12,091 tons in slopes of $5-10^{\circ}, 9318$ tons in slopes of $10-20^{\circ}$, 2156 tons in slopes of $20-30^{\circ}$ and 387 tons in slopes $>30^{\circ}$.

Table 7. LULC conversions under different slopes.

\begin{tabular}{ccccccc}
\hline \multirow{2}{*}{ LULC Conversion } & \multicolumn{4}{c}{ Area Conversions under Different Slopes } & \multirow{2}{*}{$\begin{array}{c}\text { Total Area } \\
\text { (ha) }\end{array}$} \\
\cline { 2 - 6 } & $\boldsymbol{< 5}^{\circ}$ & $\mathbf{5 - 1 0 ^ { \circ }}$ & $\mathbf{1 0 - 2 0}^{\circ}$ & $\mathbf{2 0 - 3 0 ^ { \circ }}$ & $\mathbf{3 0}^{\circ}$ & \\
\hline Grass/Shrub to farms & 82,526 & 18,830 & 6242 & 723 & 82 & 108,321 \\
Grass/Shrub to forest & 3398 & 1030 & 750 & 145 & 25 & 5322 \\
Farms to forests & 6956 & 4546 & 2367 & 505 & 246 & 14,374 \\
Farms to Grass/Shrub & 21,873 & 9378 & 5550 & 796 & 152 & 37,597 \\
Forest to farms & 20,049 & 14,478 & 11,157 & 2582 & 463 & 48,266 \\
Forest to Grass/Shrub & 4662 & 3742 & 3918 & 1010 & 173 & 13,332 \\
\hline
\end{tabular}

Table 8. Soil erosion under different LULC changes in different slopes.

\begin{tabular}{|c|c|c|c|c|c|c|c|}
\hline \multirow{2}{*}{ LULC Conversion } & \multicolumn{5}{|c|}{ Soil Erosion (Tons) } & \multirow{2}{*}{$\begin{array}{l}\text { Total } \\
\text { (Tons) }\end{array}$} & \multirow{2}{*}{$\begin{array}{l}\text { Rate } \\
\text { (t/ha) }\end{array}$} \\
\hline & $<5^{\circ}$ & $5-10^{\circ}$ & $10-20^{\circ}$ & $20-30^{\circ}$ & $>30^{\circ}$ & & \\
\hline Grass/Shrub to farms & 42,831 & 9772 & 3239 & 375 & 43 & 56,260 & 0.52 \\
\hline Grass/Shrub to forest & 1402 & 425 & 309 & 60 & 10 & 2207 & 0.41 \\
\hline Farms to forests & 2964 & 1937 & 1008 & 215 & 105 & 6229 & 0.43 \\
\hline Farms to Grass/Shrub & 9602 & 4117 & 2436 & 350 & 67 & 16,572 & 0.44 \\
\hline Forest to farms & 16,744 & 12,091 & 9318 & 2156 & 387 & 40,696 & 0.84 \\
\hline Forest to Grass/Shrub & 2211 & 1775 & 1858 & 479 & 82 & 6405 & 0.47 \\
\hline
\end{tabular}

\section{Discussion}

In this work, we examined soil erosion in western Kenya by use of the RUSLE model in a GIS environment. The study revealed that the spatial distribution of rainfall-runoff erosivity in the region was consistent with the amount of precipitation received in various parts of the study area. The highest erosivity rates computed were more to the southeastern parts of the study area, mainly in Nandi County, which falls in the Yala sub-basin, compared to the central parts of the region (Figure 3). Generally, high erosivity rates in the region are more likely to occur during the long rainfall season from mid-March to May [56]. According to Yang et al. [57] soil loss is proportional to the rate of rainfall erosivity when all the other factors are held constant, thus an important factor in the model. The study also established that the highest erodibility values (Figure 5) were found in parts of Sio sub-basin. This indicates that the soils in such areas have low stability and infiltration rates, thus they are highly vulnerable to erosion in case of heavy runoff. The soil erosion rates of 0.2 to $35.8 \mathrm{t} / \mathrm{ha} / \mathrm{y}$ (Table 4) estimated for the study area are different from those of earlier similar studies undertaken in Kenya. For example, in other regions of Kenya, the soil erosion estimates were 10-27.9 t/ha/y [58], $1-25 \mathrm{t} / \mathrm{ha} / \mathrm{y}$ [59] and 10-84.7 t/ha/y [39]. The difference in soil erosion rates among the regions is due to variability in such factors as topographic characteristics, erosivity, erodibility and vegetation cover.

In terms of soil loss severity classes, the results show that $90 \%$ of the study areas experienced soil erosion rates of low severity. Cumulatively, the annual contribution of the low severe soil erosion class is highest due to the expansive extent of their occurrence. These areas cannot be ignored in on-farm management of soil erosion since the loss of soil in these areas will systematically lower the soil quality 
through removal of silt, clay and organic content that play an important role in retaining the soil water holding capacity and structural integrity [12].

Results from spatial distribution of soil erosion risk show that the northern parts of western Kenya covering Upper Nzoia and Sio Sub-basins experience the highest rates of soil erosion compared to the southern parts. The soils in these areas are susceptible to higher erosion rates that are exacerbated by heavy runoff from the high slopes of Mt. Elgon, whose highest elevation at the study area is about $4093 \mathrm{~m}$ above mean sea level and Cherang'anyi hills that are located at an elevation of about $2286 \mathrm{~m}$ above mean sea level [60]. It also emerged from the study that the rate of soil loss increased with the increase in slope steepness (Table 6). This corroborates the findings of Ziadat and Taimeh [61] and Mati et al. [59], who concluded that the increase in slope steepness and slope length (LS-factor) increases the rate of soil erosion due to high velocity and erosivity of the runoff. According to Ali and Hagos [62], the runoff rates in such areas cause an increase in shear stress on the soil surface, leading to increased silt delivery. However, the effect of slope on runoff and soil loss is complex due to influence of other factors such as soil properties and soil surface condition [63].

In line with the results of this study, it was observed that the highest rates of soil erosion were concentrated in Mt. Elgon area in Sio sub-basin, North Eastern part of upper Nzoia sub-basin, mainly in Chereng'ayi hills and south-western parts of Yala sub-basin mainly in Elgeyo Escarpment with undulating nature of terrain. These areas are characterized by high slope length and steepness of more than $30^{\circ}$, coupled with low vegetation cover. In addition, these areas to a large extent receive higher rainfall, hence high erosivity which exacerbates soil loss and high flow accumulation in the downstream [60]. The low vegetation cover in these highly eroded areas is attributed to increased anthropogenic activities such as encroachment for settlement, farming activities and deforestation [16]. Thus, these are the areas that warrant special priority for soil conservation by the counties in order to reduce erosive capacity of water runoff and eventually solve the soil loss problem and impacts on agriculture and ecosystem services.

Comparing the soil erosion based on land use/cover types, the results revealed that soil erosion was highest in the farms compared to areas under forest, built and grass/shrub. This can be explained by the fact that there is intensive crop farming in the western region of Kenya, considering that it falls under the high agricultural potential areas. In this region, farmers practice continuous cultivation of lands for crop production, leading to degradation of soils. This results in increased rates of erosion and loss of soil organic matter content which influences the soil aggregate stability [64]. The forest and grass/shrub areas are also susceptible to soil erosion, but the rate of erosion in these areas is lower as compared to farms due to better soil cover.

A close look at the magnitude and nature of changes among the land use/cover categories show that conversion of grass/shrub and forested areas to farms was the most dominant in western Kenya (Figure 8). This type of LULC changes typically contributed to the widespread and highest quantities of soil erosion. The rather high soil erosion rates of $0.84 \mathrm{t} / \mathrm{ha}$ were recorded in farm areas cleared from forests. It is also of interest to note that forest areas cleared in slopes of more than $5^{\circ}$ were highly susceptible to the highest quantities of soil erosion compared to other LULC conversions in similar slope categories. If the trend of converting forestlands to farms continues to increase, there is a possibility of increased soil erosion, which will affect sustainability of agricultural lands for crop production in the region. Therefore, it would be necessary to minimize clearance of forests to pave way for farming, especially in steep slopes. In addition, there is a need to implement agricultural management practices to achieve sustainable soil erosion control in order to improve productivity for crop cultivation. Such practices include on-farm conservation tillage practices, water conservation and management, agroforestry practices, restoration of vegetation cover and terracing of slopes areas [14].

A major drawback of the RUSLE model is that it lacks the ability to compute soil losses from gully or stream channel erosion caused by raindrops $[2,28,65]$. Therefore, it should be taken into consideration that the soil erosion rates established in this study are primarily from sheet, rill (resulting from the 
flow of runoff) and inter-rill (resulting from the impact of raindrop on soil) erosion. However, these are the most common processes that contribute to the widespread loss of soil in agricultural lands [66].

\section{Conclusions}

This study investigated the extent of soil erosion in western Kenya by use of GIS-based RUSLE modelling approach. It is evident from the findings of the study that there is widespread soil erosion of low to moderate severity rates ranging from 0.2 to $6.8 \mathrm{t} / \mathrm{ha} / \mathrm{y}$. The highest erosion rates of between 13.4 to $35.8 \mathrm{t} / \mathrm{ha} / \mathrm{y}$ were found in parts of Mount Elgon, Cherang'anyi hills and Elgeyo escarpment, mainly due to the presence of steep slopes, high erosivity rates and degraded vegetation. The other dominant cause of soil erosion in the region are the spatial and temporal changes in land use/cover types and conversions resulting from anthropogenic activities. The highest soil erosion rates were observed in farms cleared from forests $(0.84 \mathrm{t} / \mathrm{ha}$ ) followed by those converted from grass/shrub areas $(0.52 \mathrm{t} / \mathrm{ha})$. There is therefore a need to limit clearance of forested areas for farming and minimize the rates of erosion in the region through integration of conservation measures at farm level and targeting of high erosion risk areas, mainly the degraded lands along the steep slopes where the land is bare or with low vegetation cover. Some recommended measures to prevent soil erosion are on-farm conservation tillage practices, water conservation and management, agroforest practices, restoration of vegetation cover and terracing of slopes areas. Future work on erosion assessment in the study area should examine soil loss due to gully erosion which is not currently possible using the RUSLE model. In addition, calibration of the RUSLE results with field-based experiments could help in validating the accuracy of soil erosion estimates in the study area.

Author Contributions: Conceptualization, B.K.K., L.K. and R.K.; methodology, B.K.K., L.K. and R.K.; software, B.K.K.; validation, B.K. and L.K.; formal analysis, B.K.K.; investigation, B.K.K.; resources, L.K.; data curation, B.K.K. and R.K.; writing-original draft preparation, B.K.K., writing-review and editing, B.K.K., L.K. and R.K.; visualization, B.K.K.; supervision, L.K. and R.K. All authors have read and agreed to the published version of the manuscript.

Funding: This research received no external funding.

Acknowledgments: This work was completed as part of the Ph.D. programme for the Corresponding Author who wishes to thank the University of New England, NSW, Australia, for the Scholarship Award in support of his studies.

Conflicts of Interest: The authors declare no conflict of interest.

\section{References}

1. Bai, Z.G.; Dent, D.L.; Olsson, L.; Schaepman, M.E. Proxy global assessment of land degradation. Soil Use Manag. 2008, 24, 223-234. [CrossRef]

2. Wischmeier, W.H.; Smith, D.D. Predicting Rainfall Erosion Losses: A Guide to Conservation Planning; Department of Agriculture, Science and Education Administration: Washington, DC, USA, 1978.

3. Kouli, M.; Soupios, P.; Vallianatos, F. Soil erosion prediction using the Revised Universal Soil Loss Equation (RUSLE) in a GIS framework, Chania, Northwestern Crete, Greece. Environ. Earth Sci. 2009, 57, $483-497$. [CrossRef]

4. Bonilla, C.A.; Reyes, J.L.; Magri, A. Water Erosion Prediction Using the Revised Universal Soil Loss Equation (RUSLE) in a GIS Framework, Central Chile. Chil. J. Agric. Res. 2010, 70, 159-169. [CrossRef]

5. Chan, K.Y.; Heenan, D.P.; So, H.B. Sequestration of carbon and changes in soil quality under conservation tillage on light-textured soils in Australia: A review. Aust. J. Exp. Agric. 2003, 43, 325-334. [CrossRef]

6. Gopalakrishnan, T.; Hasan, K.; Haque, A.T.M.S.; Jayasinghe, S.L.; Kumar, L. Sustainability of Coastal Agriculture under Climate Change. Sustainability 2019, 11, 7200. [CrossRef]

7. Hui, L.; Xiaoling, C.; Lim, K.J.; Xiaobin, C.; Sagong, M. Assessment of soil erosion and sediment yield in Liao watershed, Jiangxi Province, China, Using USLE, GIS, and RS. J. Earth Sci. 2010, 21, 941-953. [CrossRef]

8. Yang, X. Deriving RUSLE cover factor from time-series fractional vegetation cover for hillslope erosion modelling in New South Wales. Soil Res. 2014, 52, 253-261. [CrossRef]

9. Lal, R. Soil degradation by erosion. Land Degrad. Dev. 2001, 12, 519-539. [CrossRef] 
10. Panagopoulos, Y.; Dimitriou, E.; Skoulikidis, N.T. Vulnerability of a Northeast Mediterranean Island to Soil Loss. Can Grazing Management Mitigate Erosion? Water 2019, 11, 1491. [CrossRef]

11. Kiage, L. Perspectives on the assumed causes of land degradation in the rangelands of Sub-Saharan Africa. Prog. Phys. Geogr. Earth Environ. 2013, 37, 664-684. [CrossRef]

12. Sanchez, P.A.; Palm, C.A.; Buol, S.W. Fertility capability soil classification: A tool to help assess soil quality in the tropics. Geoderma 2003, 114, 157-185. [CrossRef]

13. Ringius, L.; Downing, T.; Hulme, M.; Waughray, D.; Selrod, R. Climate change in Africa: Issues and challenges in agriculture and water for sustainable development. Cicero Rep. 1996, 8, 84-96.

14. Mulinge, W.; Gicheru, P.; Murithi, F.; Maingi, P.; Kihiu, E.; Kirui, O.K.; Mirzabaev, A. Economics of Land Degradation and Improvement in Kenya. In Economics of Land Degradation and Improvement-A Global Assessment for Sustainable Development; Springer: Cham, Switzerland, 2016; pp. 471-498.

15. Bai, Z.; Dent, D. Global assessment of land degradation and improvement: Pilot study in Kenya. ISRIC Rep. 2006, 1, 3-16.

16. Kogo, B.K.; Kumar, L.; Koech, R. Forest cover dynamics and underlying driving forces affecting ecosystem services in western Kenya. Remote Sens. Appl. Soc. Environ. 2019, 14, 75-83. [CrossRef]

17. Waswa, B.S. Assessment of Land Degradation Patterns in Western Kenya: Implications for Restoration and Rehabilitation. Ph.D. Thesis, Universitäts-und Landesbibliothek Bonn, Bonn, Germany, 2012.

18. Ngome, A.F.; Becker, M.; Mtei, K.M.; Mussgnug, F. Fertility management for maize cultivation in some soils of Western Kenya. Soil Tillage Res. 2011, 117, 69-75. [CrossRef]

19. Tittonell, P.; Vanlauwe, B.; De Ridder, N.; Giller, K. Heterogeneity of crop productivity and resource use efficiency within smallholder Kenyan farms: Soil fertility gradients or management intensity gradients? Agric. Syst. 2007, 94, 376-390. [CrossRef]

20. Borrelli, P.; Robinson, D.A.; Panagos, P.; Lugato, E.; Yang, J.E.; Alewell, C.; Wuepper, D.; Montanarella, L.; Ballabio, C. Land use and climate change impacts on global soil erosion by water (2015-2070). Proc. Natl. Acad. Sci. USA 2020, 117, 21994-22001. [CrossRef]

21. Chen, T.; Niu, R.-Q.; Li, P.-X.; Zhang, L.; Du, B. Regional soil erosion risk mapping using RUSLE, GIS, and remote sensing: A case study in Miyun Watershed, North China. Environ. Earth Sci. 2010, 63, 533-541. [CrossRef]

22. Wang, G.; Gertner, G.; Fang, S.; Anderson, A.B. Mapping Multiple Variables for Predicting Soil Loss by Geostatistical Methods with TM Images and a Slope Map. Photogramm. Eng. Remote Sens. 2003, 69, 889-898. [CrossRef]

23. Bartsch, K.P.; Van Miegroet, H.; Boettinger, J.; Dobrowolski, J.P. Using empirical erosion models and GIS to determine erosion risk at Camp Williams, Utah. J. Soil Water Conserv. 2002, 57, 29-37.

24. Evans, R. An alternative way to assess water erosion of cultivated land-field-based measurements: And analysis of some results. Appl. Geogr. 2002, 22, 187-207. [CrossRef]

25. Evans, R.; Brazier, R. Evaluation of modelled spatially distributed predictions of soil erosion by water versus field-based assessments. Environ. Sci. Policy 2005, 8, 493-501. [CrossRef]

26. Renschler, C.S.; Harbor, J. Soil erosion assessment tools from point to regional scales-The role of geomorphologists in land management research and implementation. Geomorphology 2002, 47, 189-209. [CrossRef]

27. Karydas, C.G.; Panagos, P.; Gitas, I.Z. A classification of water erosion models according to their geospatial characteristics. Int. J. Digit. Earth 2012, 7, 229-250. [CrossRef]

28. Renard, K.G. Predicting Soil Erosion by Water: A Guide to Conservation Planning with the Revised Universal Soil Loss Equation (RUSLE); United States Government Printing: Washington, DC, USA, 1997.

29. Kinnell, P. Event soil loss, runoff and the Universal Soil Loss Equation family of models: A review. J. Hydrol. 2010, 385, 384-397. [CrossRef]

30. Diodato, N.; Borrelli, P.; Fiener, P.; Bellocchi, G.; Romano, N. Discovering historical rainfall erosivity with a parsimonious approach: A case study in Western Germany. J. Hydrol. 2017, 544, 1-9. [CrossRef]

31. Mustefa, M.; Fufa, F.; Takala, W. GIS estimation of annual average soil loss rate from Hangar River watershed using RUSLE. J. Water Clim. Chang. 2019, 11, 529-539. [CrossRef]

32. Panagos, P.; Borrelli, P.; Poesen, J.; Ballabio, C.; Lugato, E.; Meusburger, K.; Montanarella, L.; Alewell, C. The new assessment of soil loss by water erosion in Europe. Environ. Sci. Policy 2015, 54, 438-447. [CrossRef] 
33. Naqvi, H.R.; Mallick, J.; Devi, L.M.; Siddiqui, M.A. Multi-temporal annual soil loss risk mapping employing Revised Universal Soil Loss Equation (RUSLE) model in Nun Nadi Watershed, Uttrakhand (India). Arab. J. Geosci. 2012, 6, 4045-4056. [CrossRef]

34. Angima, S.; Stott, D.; O’Neill, M.; Ong, C.; Weesies, G. Soil erosion prediction using RUSLE for central Kenyan highland conditions. Agric. Ecosyst. Environ. 2003, 97, 295-308. [CrossRef]

35. Shi, Z.; Cai, C.; Ding, S.; Wang, T.; Chow, T. Soil conservation planning at the small watershed level using RUSLE with GIS: A case study in the Three Gorge Area of China. Catena 2004, 55, 33-48. [CrossRef]

36. Nasir, A.; Uchida, K.; Ashraf, M. Estimation of soil erosion by using RUSLE and GIS for small mountainous watersheds in Pakistan. Pak. J. Water Resour. Pak. 2006, 10, 11-21.

37. Lu, D.; Li, G.; Valladares, G.S.; Batistella, M. Mapping soil erosion risk in Rondônia, Brazilian Amazonia: Using RUSLE, remote sensing and GIS. Land Degrad. Dev. 2004, 15, 499-512. [CrossRef]

38. Onyando, J.O.; Kisoyan, P.; Chemelil, M.C. Estimation of Potential Soil Erosion for River Perkerra Catchment in Kenya. Water Resour. Manag. 2005, 19, 133-143. [CrossRef]

39. Mutua, B.; Klik, A.; Loiskandl, W. Modelling soil erosion and sediment yield at a catchment scale: The case of Masinga catchment, Kenya. Land Degrad. Dev. 2006, 17, 557-570. [CrossRef]

40. Pandey, A.; Chowdary, V.M.; Mal, B.C. Identification of critical erosion prone areas in the small agricultural watershed using USLE, GIS and remote sensing. Water Resour. Manag. 2006, 21, 729-746. [CrossRef]

41. Mora, B.; Tsendbazar, N.-E.; Herold, M.; Hagolle, O. Global Land Cover Mapping: Current Status and Future Trends. In Land Use and Land Cover Mapping in Europe; Springer: Berlin/Heidelberg, Germany, 2014; pp. 11-30.

42. Yang, D.; Kanae, S.; Oki, T.; Koike, T.; Musiake, K. Global potential soil erosion with reference to land use and climate changes. Hydrol. Process. 2003, 17, 2913-2928. [CrossRef]

43. Jaetzold, R.; Schmidt, H. Farm Management Handbook of Kenya; Ministry of Agriculture: Nairobi, Kenya, 1982.

44. Omuto, C.T. Kenya: A Natural Outlook: Chapter 11. Major Soil and Data Types in Kenya; Elsevier Inc.: Amsterdam, The Netherlands, 2013; Volume 16.

45. Kogo, B.K.; Kumar, L.; Koech, R. Analysis of spatio-temporal dynamics of land use and cover changes in Western Kenya. Geocarto Int. 2019, 1-16. [CrossRef]

46. Renard, K.G.; Foster, G.R.; Weesies, G.A.; Porter, J.P. RUSLE: Revised universal soil loss equation. J. Soil Water Conserv. 1991, 46, 30-33.

47. Lu, G.Y.; Wong, D.W. An adaptive inverse-distance weighting spatial interpolation technique. Comput. Geosci. 2008, 34, 1044-1055. [CrossRef]

48. Pokhrel, R.M.; Kuwano, J.; Tachibana, S. A kriging method of interpolation used to map liquefaction potential over alluvial ground. Eng. Geol. 2013, 152, 26-37. [CrossRef]

49. Shahbeik, S.; Afzal, P.; Maarefvand, P.; Qumarsy, M. Comparison between ordinary kriging (OK) and inverse distance weighted (IDW) based on estimation error. Case study: Dardevey iron ore deposit, NE Iran. Arab. J. Geosci. 2013, 7, 3693-3704. [CrossRef]

50. KENSOTER Home Page. Available online: https://research.wur.nl/en/datasets/soter-based-soil-parameterestimates-sotwis-for-kenya-version-10 (accessed on 12 May 2020).

51. Sharpley, A.N.; Williams, J.R. EPIC-Erosion/Productivity Impact Calculator. I: Model Documentation. II: User Manual; Technical Bulletin; United States Department of Agriculture: Washington, DC, USA, 1990; p. 1768.

52. Morgan, R.P.C. Soil Erosion and Conservation; John Wiley \& Sons: Hoboken, NJ, USA, 2009.

53. Singh, G.; Chandra, S.; Babu, R. Soil loss and prediction research in India, Central Soil and Water Conservation Research Training Institute. Bulletin No T-12 D 1981, 9, 1981.

54. Van der Knijff, J.; Jones, R.; Montanarella, L. Soil Erosion Risk Assessment in Europe, EUR 19044 EN; Office for Official Publications of the European Communities: Luxembourg, 2000; p. 34.

55. Gitas, I.Z.; Douros, K.; Minakou, C.; Silleos, G.N.; Karydas, C.G. Multi-temporal soil erosion risk assessment in N. Chalkidiki using a modified USLE raster model. EARSeL Proc. 2009, 8, 40-52.

56. Mugalavai, E.M.; Kipkorir, E.C.; Raes, D.; Rao, M.S. Analysis of rainfall onset, cessation and length of growing season for western Kenya. Agric. For. Meteorol. 2008, 148, 1123-1135. [CrossRef]

57. Yang, X.; Gao, W.; Shi, Q.; Chen, F.; Chu, Q. Impact of climate change on the water requirement of summer maize in the Huang-Huai-Hai farming region. Agric. Water Manag. 2013, 124, 20-27. [CrossRef]

58. Hategekimana, Y.; Allam, M.; Meng, Q.; Nie, Y.; Elhag, M. Quantification of Soil Losses along the Coastal Protected Areas in Kenya. Land 2020, 9, 137. [CrossRef] 
59. Mati, B.M.; Morgan, R.P.; Gichuki, F.N.; Quinton, J.N.; Brewer, T.R.; Liniger, H.P. Assessment of erosion hazard with the USLE and GIS: A case study of the Upper Ewaso Ng'iro North basin of Kenya. Int. J. Appl. Earth Obs. Geoinf. 2000, 2, 78-86. [CrossRef]

60. Dulo, S.; Odira, P.; Nyadwa, M.; Okelloh, B. Integrated flood and drought management for sustainable development in the Nzoia River Basin. Nile Basin Water Sci. Eng. J. 2010, 3, 39-51.

61. Ziadat, F.M.; Taimeh, A.Y. Effect of rainfall intensity, slope, land use and antecedent soil moisture on soil erosion in an arid environment. Land Degrad. Dev. 2013, 24, 582-590. [CrossRef]

62. Ali, S.A.; Hagos, H. Estimation of soil erosion using USLE and GIS in Awassa Catchment, Rift valley, Central Ethiopia. Geoderma Reg. 2016, 7, 159-166. [CrossRef]

63. Gabarrón-Galeote, M.A.; Martínez-Murillo, J.F.; Ruiz-Sinoga, J.D. Relevant effects of vegetal cover and litter on the soil hydrological response of two contrasting Mediterranean hillslopes at the end of the dry season (south of Spain). Hydrol. Process. 2011, 26, 1729-1738.

64. Barbera, V.; Poma, I.; Gristina, L.; Novara, A.; Egli, M. Long-term cropping systems and tillage management effects on soil organic carbon stock and steady state level of $C$ sequestration rates in a semiarid environment. Land Degrad. Dev. 2010, 23, 82-91. [CrossRef]

65. Koirala, P.; Thakuri, S.; Joshi, S.; Chauhan, R. Estimation of Soil Erosion in Nepal Using a RUSLE Modeling and Geospatial Tool. Geosciences 2019, 9, 147. [CrossRef]

66. Borrelli, P.; Robinson, D.A.; Fleischer, L.R.; Lugato, E.; Ballabio, C.; Alewell, C.; Meusburger, K.; Modugno, S.; Schütt, B.; Ferro, V.; et al. An assessment of the global impact of 21st century land use change on soil erosion. Nat. Commun. 2017, 8, 1-13. [CrossRef] [PubMed]

Publisher's Note: MDPI stays neutral with regard to jurisdictional claims in published maps and institutional affiliations. 